\title{
BODIES AND POLITICS IN LUKE 1-2 AND SIRACH 44-50: MEN, WOMEN, AND BOYS
}

\author{
Vernon K Robbins \\ Emory University \\ Extraordinary Professor \\ Stellenbosch University
}

\begin{abstract}
Alternative body politics place the body in the world and the world in the body in decisively different ways. Luke 1-2 uses a priestly offering of incense in the Jerusalem Temple to begin a body politics that establishes prophetic wisdom in family households. Sirach 44-50, in contrast, uses worship led by the high priest Simon to establish a priestly body politics that brings Woman Wisdom into the Jerusalem Temple. When ritual actions and pronouncements of blessing occur not only in the Jerusalem Temple but also in "family households of God" in Luke, distinctly different "bodies" bring priestly blessing in "holy locations" and distinctly different guidelines determine "inclusion" and "exclusion." Reversing the body politics of Sirach, Luke 1-2 configures the Jerusalem Temple as a house of God that empowers a new group of "famous men and women" for God's mighty work in the world.
\end{abstract}

Keywords: Bless/Blessing(s), Prophet/Prophetic, Priest/Priestly, Rhetorolect, Wisdom

\section{Body in the World and World in the Body}

The special topic of this paper is the manner in which the body is present in language and in interpretation of language, and how "politics" develops in, through, and around language about bodies. The topic emerges in an environment where some literary interpreters are talking about a transition from a "linguistic turn" during the twentieth century to a "corporeal turn" at the beginning of the twenty-first century. ${ }^{1}$ A major issue is how humans fill words with meaning. Ruthrof (2000, vii) argues that "the body is always already part of language as discourse." Gleaning insights from Peirce, Husserl, Heidegger, Wittgenstein and Derrida, and drawing on recent research in cognitive science, cognitive linguistics and cognitive rhetoric, he develops a position he calls "corporeal semantics." From this perspective, "When a meaning event occurs, the body enters language in the form of quasiperceptual readings of the world." negotiating language by means of "the body" in the form of nonverbal signs. "The body is present in discourse in the form of nonlinguistic signs: As olfactory, tactile, gustatory, aural, visual, and many other subtle, nonverbal readings of the world."

Ruthrof, H 2000. The Body in Language. London and New York: Cassell, 6-21.

Ruthrof $(2000,1)$.

Ruthrof (2000, vii). 
This paper will not address the relation of corporeal semantics to cognitive semantics, ${ }^{4}$ nor will it address the fundamental function of nonverbal signs in the production of meaning in language. ${ }^{5}$ Rather, it will start with an observation made during the $18^{\text {th }}$ century by Vico that humans give meaning to the world outside of them by using terms related to their bodies. The result is the presence of "body language" in the world:

Thus, head for top or beginning; the brow and shoulders of a hill; the eyes of needles and of potatoes; mouth for any opening; the lip of a cup or pitcher; the teeth of a rake, a saw, a comb; the beard of wheat; the tongue of a shoe; the gorge of a river; a neck of land; an arm of the sea; the hands of a clock; heart for centre (the Latin uses umbilicus, navel, in this sense); the belly of a sail; foot for end or bottom; the flesh of fruits; a vein of rock or mineral; the blood of grapes for wine; the bowels of the earth. Heaven or the sea smiles; the wind whistles; the waves murmur; a boat groans under a great weight. The farmers of Latium used to say the fields were thirsty, bore fruit, were swollen with grain; and our rustics speak of plants making love, vines going mad, resinous trees weeping. ${ }^{6}$

A very important part of meaningful language is a matter of placing "body" in the world. And in the midst of this, we know not to try to thread the eye of a needle with the hands of a clock, or to lick the lip of a cup with the tongue of a shoe! In other words, we place our body in the world in ways that we understand and can negotiate without significant difficulties.

In the context of human activity in which we place "body" in the world, it is remarkable how pervasively early Christian discourse places "world" in the body. All of us are familiar with the exhortation in 1 Pet 2:5 that, "like living stones," followers of Christ should let themselves "be built into a spiritual house." We also know that "the eye is the lamp of the body" (Matt 6:22; cf. Luke 11:34) and that Jesus is "the vine" and those who "abide in him" are "the branches" (John 15:5). And we seem to know what is meant when it says that bodies should be full of light (Luke 11:34-36).

With these things in mind, the beginning place for interpretation in this paper is a commitment to a theory of semantic corporeality. ${ }^{7}$ The analysis is grounded in a sociorhetorical presupposition that bodies are essential participants in the creation of meaning in a text. In other words, the interpreter is committed to an approach that places body in mind and mind in body, intentionally moving away from a post-Kantian body-mind dualism. ${ }^{8}$ In addition, the interpreter is committed to an analysis of "culture" in body and mind. ${ }^{9}$ Building on Vico's insight that humans place their bodies in the world to create a meaningful world, this paper moves into the ways in which humans create different kinds of "bodies" by placing different social and cultural spaces into them. The issue, then, is society and culture in body and mind. One of the questions is: "How do you place a house,

Ruthrof $(2000,166-168)$.

Ruthrof $(2000,22-139)$.

Vico, G 1968. The New Science of Giambattista Vico. New York: Cornell University Press, [405], 129. Quoted in Ruthrof $(2000,38)$.

Ruthrof (2000, 7). See also Johnson, M 1987. The Body in the Mind: The Bodily Basis of Meaning, Imagination, and Reason. Chicago: University of Chicago Press.

8 Vorster, JN 1997. Construction of Culture through the Construction of Person: The Acts of Thecla as an Example. Pages 447-457 in The Rhetorical Analysis of Scripture: Essays from the 1995 London Conference. Edited by SE Porter and TH Olbricht. Journal for the Study of the New Testament: Supplement Series 146. Sheffield: Sheffield Academic Press; Robbins, VK 1996. The Tapestry of Early Christian Discourse: Rhetoric, Society and Ideology. London: Routledge, 6-10, 26-30.

9 Shore, B 1996. Culture in Mind: Cognition, Culture, and the Problem of Meaning. Oxford: Oxford University Press; Robbins, VK 1996. Making Christian Culture in the Epistle of James. Scriptura 59:341-351. 
a kingdom, or parts of the created world into a human body?" If we can begin to answer this question, another question is: "Why?" Why would anyone want to place a house, a kingdom, or parts of the created world into a human body? The answer is political: A matter of creating a political space, a polis, where there is order. "Significant others" mediate society and culture to a new member of the world, selecting "aspects of it in accordance with their own location in the social structure, and also by virtue of their individual, biographically rooted idiosyncrasies." ${ }^{, 10}$ Those who make the selections and mediate them are "brokers," mediators who move power and benefits of power around in the world. ${ }^{11}$ Movement of "order" is therefore movement of power.

The author of this paper presupposes that early Christian discourse blended six different types of "Christian body" together through the medium of six different rhetorolects: Wisdom, miracle, prophetic, priestly, precreation, and apocalyptic. "A rhetorolect is a form of language variety or discourse identifiable on the basis of a distinctive configuration of themes, topics, reasonings, and argumentations." 12 Each rhetorolect blends "locations" in the world with the human body in distinctive ways. In addition, it blends the human body with "locations" in the world. This reciprocal activity between the human body and "locations" creates a dynamic system of Christian discourse that simultaneously reconfigures images of the human body and images of locations in the world.

This paper engages in the beginning steps of an investigation that exhibits the manner in which the Jerusalem temple and households in Luke interact reciprocally with human bodies to create prophetic, priestly bodies who move the story forward into households, where prophetic speech creates new configurations of "holy community," and finally back into the Jerusalem temple, where a new community of men and women "live daily" until special promises occur. These beginning steps focus on the first two chapters of the Gospel of Luke to analyze the ways in which divine powers in the Temple move out into households through the bodies of Zechariah, Elizabeth, and Mary, and subsequently into John the Baptist and Jesus. The analysis and interpretation begins directly with Luke 1:5, where events occur that lead to the birth and infancy of John the Baptist and Jesus.

\section{Zechariah and Elizabeth Take Center Stage in Luke 1:5-7}

Lukan narration ${ }^{13}$ in 1:5 begins in a manner that evokes seven mental spaces ${ }^{14}$ for human bodies or body-like personages: King Herod of Judea; a priest named Zechariah; a priest named Abijah, of whom Zechariah is a descendant; a priestly wife named Elizabeth; a priest named Aaron, who is the "founding father" of Elizabeth's family; a child who has not been born to Zechariah and Elizabeth; and God.

Herod, king of Judea, is mentioned only once in Luke (1:5). His body serves only as "background," evoking a temporal-spatial location for the events that bring forth the births

10 Berger, PL and T Luckmann. 1967. The Social Construction of Reality: A Treatise in the Sociology of Knowledge. Anchor Books. New York: Doubleday, 131.

11 Malina, BJ 1993. The New Testament World: Insights from Cultural Anthropology. Rev. (ed.) Louisville: Westminster John Knox, 102.

12 Robbins, VK 1996. The Dialectical Nature of Early Christian Discourse. Scriptura 59:356.

13 From the perspective of this essay, Luke 1:1-4 is paranarration, namely narration about the narrative itself (Oakley, TV 1998. Conceptual Blending, Narrative Discourse, and Rhetoric. Cognitive Linguistics 9(4):331).

14 Fauconnier, G 1994. Mental Spaces: Aspects of Meaning Construction in Natural Language. Cambridge: Cambridge University Press. 
of John and Jesus. ${ }^{15}$ Lukan narration uses eight Greek words to name Herod and refer to the location of the story in "Judea" during "the days of King Herod." Political boundaries within time and geo-physical space establish the location for the opening part of the Lukan story: A time and place in which a man named Herod reigned as king.

The Gospel of Luke never mentions King Herod of Judea again, although members of the Herodian family appear in five later chapters as the story progresses. ${ }^{16}$ Thus, King Herod exists in the background, functioning as the "founding father" of political government. The Gospel of Matthew, in contrast to Luke, brings King Herod prominently into the story of Jesus' birth and childhood. Referring to Herod nine times by name, ${ }^{17}$ Matthew's account creates a dynamic relation between the "religious politics" surrounding the birth and childhood of Jesus and the religious politics of Israel's journey from the land of Canaan to Egypt and then back out of Egypt into the land of Canaan. The Gospel of Luke, in contrast to Matthew, uses the political presence of King Herod only as background for a story that begins in the Jerusalem Temple.

Lukan narration refers to Abijah when it introduces Zechariah and to Aaron when it introduces Elizabeth. Aaron, the brother of Moses, was the "founding father" of priestly families in Israel (Exod 28:1-43). Abijah was a grandson of Aaron, receiving responsibility by lot for the eighth course of service in the Jerusalem Temple (1 Chr 24:10, 19). A man with a family heritage going back to Abijah would probably travel from his household to Jerusalem twice a year to perform a week of daily duties in the Temple. ${ }^{18}$ Lukan narration embodies both Elizabeth and Zechariah with priestly heritage that reaches back to Aaron, the brother of Moses, whom God gave responsibility for all priestly things in Israel. Aaron functions as the "founding father" of priesthood in the Lukan story, then, much like Herod functions as the founding father of political government.

There is only one reference in Luke to Abijah and one to Aaron (Luke 1:5), like there is only one reference to Herod, king of Judea. A major difference emerges, however, when Lukan narration uses fifty-four Greek words in 1:5-7 to bring the priestly attributes of Zechariah and Elizabeth into the foreground of the story. After Luke 1:5 introduces the names and ancestors of Zechariah and Elizabeth, 1:6 presents them as inter-related "priestly" bodies of action. In the spirit of Gen 2:24, this priestly male and female function as "one flesh." Together, they were "righteous before God, living blamelessly according to all the commandments and regulations of the Lord" (1:6). Their bodies functioned in unity as they enacted the most honorable deeds of priestly heritage possible to humans on earth. By all accounts, their actions should be at the center of Israel's functioning as "a priestly kingdom and a holy nation" (Exod 19:6).

There is, however, a problem. The "priestly flesh" of Zechariah and Elizabeth has produced no offspring. Is this deficiency in blessing the result of a problematic relation between political and priestly domains in the kingdom of Judea? In other words, do people with special holiness in Herod's kingdom not receive abundant blessings from God as a result of "evil" in the political realm? Or is there somehow a problem in the Temple itself that causes the righteous people of Israel not to receive God's blessings? Is this a story where miraculous powers in God's Temple will bring forth children who rise up against the

15 Ruthrof $(2000,48)$ : "Together, spatial and temporal deixis govern the technical aspects of the point of view from which a text is spoken."

$16 \quad$ Luke $3(1,19) ; 8(3) ; 9(7,9) ; 13(31) ; 23(7,8,11,12,15)$.

17 Matt 2:1, 3, 7, 12, 13, 15, 16, 19, 22. After this, there are only three references to a member of the Herodian family in the Matthean account: $14: 1,3,6$

18 Fitzmyer, JA 1981. The Gospel According to Luke (I-IX). Anchor Bible 28. New York: Doubleday, 322. 
political powers in the region, or will they somehow reform the Temple? Or will these children rise up against both the political powers and the Jerusalem Temple?

No narrational commentary tells the hearer or reader why Zechariah and Elizabeth are childless, but first century "cultural knowledge" probably created an expectation that Zechariah and Elizabeth would "miraculously" have a child during their advanced years. There would also be an expectation that this child would somehow play a role in religiouspolitical renewal. This new story, then, is really an old story. The newness of the story will emerge from the particular way in which Zechariah and Elizabeth hear the news that they will have a child and the particular circumstances that surround the birth and infancy of the child.

As Lukan narration unfolds, it creates a mental space for an unborn child in the context of Herod, king of Judea; a priest named Zechariah; a priestly order of Abijah; a priestly wife named Elizabeth; and a priestly family descended from Aaron. But a divine being also has emerged, with alternative names of "God" and "the Lord" (1:6). This being named God and the Lord has a greater presence in relation to the bodies of Zechariah and Elizabeth than Herod, Abijah, or Aaron. The righteousness of Zechariah and Elizabeth is righteousness "before God" (1:6, enantion tou theou). The narration evokes an image of God "opposite" Zechariah and Elizabeth, as though God were continually on the other side of an envisioned space that includes God, Zechariah, and Elizabeth. The importance of God's presence is underscored by the "commandments and regulations of the Lord" which guide Zechariah and Elizabeth as they "blamelessly" enact righteousness with their bodies (1:6). In other words, Zechariah and Elizabeth give priority in their lives to the personage and decrees of God, rather than the personage and regulations of Herod, the king of Judea. This is, again, an old story in the story of Israel. But every old story has the potential to be a new story. What will be new about this old story?

\section{Zechariah Enters the Temple in Luke 1:8-10}

The next fifty-four Greek words in Lukan narration (1:8-10) introduce decisively new personages engaged in new actions. When the narration brings Zechariah onto centre stage, performing his duties in the Temple (1:8-9), it also brings into focus "a whole multitude of people praying outside at the time of the incense offering" (1:10). Lukan foregrounding of the "blameless" bodily enactment of priestly heritage by Zechariah and Elizabeth moves fully onto center stage in 1:8-9 when Zechariah enters "the sanctuary of the Lord" to serve "as priest before God." When Lukan narration repeats the phrases "before God" (1:8) and "of the Lord" (1:9), the hearer or reader conceptually blends the space that contained Zechariah, Elizabeth, and God (1:6) with the Jerusalem Temple, which contains Zechariah and God (1:8-9). And now a very important question emerges: Is the initial space containing Zechariah, Elizabeth, and God implicitly the "household" of Zechariah and Elizabeth, or is it a space that could be located anywhere "in God's cosmos"? My conclusion is that the hearer or reader creates an implicit image of the bodies of Zechariah and Elizabeth in a household. The reason lies in the presupposition in the narration that they should have a child. Lukan narration makes a transition from the household of Zechariah and Elizabeth, where God is present at all times to both Zechariah and Elizabeth - and a child also should be present - to the household of God, into which only Zechariah can enter to serve as a priest before God.

And now we must make another decision. Is Zechariah's body separate from Elizabeth's body as he enters the Temple, or is it still an inter-related unity with Elizabeth's 
body? Lukan narration indicates that Zechariah's body is still thoroughly unified with Elizabeth's body, but here we enter into a very important step in "body politics." In the context where Zechariah's body enters the Temple, the hearer or reader sees that his "priestly" body has a special relation not only to a "blamelessly righteous" wife (1:6) but also to a "whole multitude of praying people" (1:10). The "double-focus" in this new space introduces another "religious politics." Zechariah's male body is invested "politically" with authority to move "closer" to the presence of God than either his priestly wife or the "whole" multitude of people who stay on the outside and pray. At this point, then, Lukan narration leaves whatever politics may exist between King Herod and the Temple in the background and places the "body politics" of a priest in the Jerusalem Temple in the foreground.

In other words, Lukan narration elaborates priestly rather than political rhetorolect as it moves from background information, which includes political reference, into a story about Zechariah and Elizabeth. The priestly focus of the narration brings forth one of the most vivid pictures of priestly activity in New Testament discourse. The initial focus is on purposeful action by Zechariah's body, which accords fully with the focus on Zechariah's and Elizabeth's purposeful enactment of "blameless" righteousness in 1:6. As Zechariah's feet carry him into the sanctuary of the Lord, where he will use his hands to offer the burning offering of incense, the hearer or reader is transported into the Jerusalem Temple. When Zechariah comes to the special incense altar, he is standing just outside the curtain that shields the Holy of Holies from view. ${ }^{19}$

\section{Wisdom Enters the Temple in Sirach 44-50}

At this point, a recent study by Camp (2002) can help our analysis and interpretation of Luke 1-2. She focuses on Sirach 44-50 to exhibit how the text of Sirach "tells" a Temple. ${ }^{20}$ In Sirach's "person story" of Israel, Aaron receives the longest description of all the "famous men" of Israel except for the high priest Simon, son of Onias, who forms the conclusion. ${ }^{21}$ Of particular interest for our investigation of Luke 1-2 is the depiction of the high priest Simon in Sirach 50:1-21.

First, Sirach 50:1-4 describes the high priest Simon on the basis of his purposive action concerning the Temple and the city in which the Temple was located. He "repaired the house," "fortified the sanctuary," "laid the foundation for the high double walls," "dug a water cistern," "considered how to keep his people from ruin," and "strengthened the city against siege."

19 See Mishnah Yoma 5:1 (Danby, H 1985. The Mishnah. Oxford: Oxford University Press, 167): [Description of the High Priest's entry into the Holy of Holies on the Day of Atonement:] The outer curtain was looped up on the south side and the inner one on the north side. He went along between them until he reached the north side; when he reached the north he turned round to the south and went on with the curtain on his left hand until he reached the Ark. When he reached the Ark he put the fire pan between the bars. He heaped up the incense on the coals and the whole place became filled with smoke. He came out by the way he went in, and in the outer space he prayed a short prayer. But he did not prolong his prayer lest he put Israel in terro (Boring, ME, K Berger and C Colpe. 1995. Hellenistic Commentary to the New Testament. Nashville: Abingdon Press, 184-185).

20 Camp, CV 2002. Storied Space, or Ben Sira “Tells" a Temple. Pages 64-80 in "Imagining” Biblical Worlds: Studies in Spatial, Social and Historical Constructs in Honor of James W Flanagan. Edited by DM Gunn and PM McNutt. Journal for the Study of the Old Testament: Supplement Series 359. Sheffield: Sheffield Academic Press.

21 Sirach 45:6-22; 50:1-21; Camp (2002, 75). 
Second, Sirach 50:5-8 describes the high priest Simon's body in relation to God's created cosmos to depict "how glorious he was, surrounded by the people, as he came out of the house of the curtain" (50:5). This description is a matter of blending God's good and bounteous creation, which is the primary image undergirding wisdom rhetorolect, ${ }^{22}$ with the body of the high priest Simon. At the moment Simon comes out of the house of the curtain, he is like the morning star among the clouds, the full moon at the festal season, the sun shining on the Temple of the Most High, the rainbow gleaming in splendid clouds, roses in the days of first fruits, lilies by a spring of water, a green shoot on Lebanon on a summer day (50:6-8), an olive tree laden with fruit, and a cypress towering in the clouds $(50: 10)$.

In the midst of the blending of the high priest with God's bounteous cosmos, he is also blended with the special materials of the house of God. The high priest Simon is like fire and incense in the censer, and he is like a vessel of hammered gold studded with all kinds of precious stones (50:9).

The description of the high priest Simon in Sirach 50 can help us understand how the Gospel of Luke is reconfiguring the space of the Jerusalem Temple in the mind of the hearer or reader. Sirach 50 focuses on the high priest, rather than on a priest who performs daily duties in the Temple. This sets the stage for a very different picture of the relation of the priest to the assembly of people related to him. In Sirach 50, the high priest gives the congregation direct access to blessings as they are able to see things inside the temple. Sirach 50:5 describes the high priest in glorious array, "surrounded by the people, as he came out of the house of the curtain." The people quite obviously see the high priest, just as the hearer or reader sees him, as he performs his priestly activities in the Temple. As he goes up to the holy altar, the high priest makes "the court of the sanctuary glorious" (11). At this point there is an amazingly vivid sequence of activity by the high priest, "all the sons of Aaron," "all the people," and the singers:

1) The high priest "received the portions from the hands of the priests, as he stood by the hearth of the altar with a garland of brothers around him." At this point the high priest is "like a young cedar on Lebanon, surrounded by the trunks of palm trees" (12).

2) In this context "all the sons of Aaron in their splendor held the Lord's offering in their hands, before the whole congregation of Israel" (13).

3) When the high priest finished his rituals and the offering at the altars (14) "he held out his hand for the cup and poured a drink offering of the blood of the grape; he poured it out at the foot of the altar, a pleasing odor to the Most High, the king of all" (15).

4) At this point "the sons of Aaron shouted; they blew their trumpets of hammered metal; they sounded a mighty fanfare as a reminder before the Most High" (16).

5) "Then all the people together quickly fell to the ground on their faces to worship their Lord, the Almighty, God Most High" (17).

6) "Then the singers praised him with their voices in sweet and full-toned melody" (18).

7) "And the people of the Lord Most High offered their prayers before the Merciful One, until the order of worship of the Lord was ended, and they completed his ritual" (19).

8) "Then Simon came down and raised his hands over the whole congregation of Israelites, to pronounce the blessing of the Lord with his lips, and to glory in his name" (20).

9) "And they bowed down in worship a second time, to receive the blessing from the Most High" (21).

22 Sirach 24:13-22 describes the manner in which wisdom becomes good and bounteous creation. 
This remarkable picture of the high priest, "all the sons of Aaron," the "whole congregation of Israel," and the singers is the result of a blend of biblical wisdom tradition with biblical priestly tradition. Instead of seeing the magnificent pilasters, entrance, sidewalls, inner room, side chambers, passageway from story to story, stairway, raised platform, chambers of the court, etcetera of the Temple (Ezek 41:1-42:12), which is characteristic of priestly tradition, the hearer or reader sees "people," which is characteristic of wisdom tradition. The Temple is in the background, while people are in the foreground. In Sirach, the Jerusalem Temple has become a "house of God" filled with glorious people who have attributes of God's bounteous, fruitful creation!

\section{Receiving Blessings in the Temple in Luke 1:11-25}

In the Gospel of Luke, Zechariah is not a high priest. He is an "ordinary" priest who performs "daily duties" in the Temple during two weekly time periods each year. This ordinary priest brings powers of God out of the Temple by means of his body and takes these powers into his household. This is the beginning of a story in which God's miraculous powers move from the Jerusalem Temple into two households in such a manner that these households, rather than the Temple as "the house of God," become God's "power base" for the renewal of Israel.

As the story unfolds in Luke, a picture of the Jerusalem Temple and the people of Israel that is very different from Sirach emerges in the mind of the hearer or reader. First, the "whole" multitude of people are restricted to an area "outside" the sanctuary (Luke 1:10). This means they are not able to see what Zechariah does nor participate in an overall ceremony of song, praise, and bowing down in worship (cf. Sirach 50:17-21). Second, an unexpected and astonishing event occurs during the incense offering that transmits a special kind of blessing into the bodies of two inter-related priestly people. This focusing of God's blessings creates a dramatically different function for the Jerusalem Temple. Instead of being an open location filled with glorious people who participate in God's bounteous blessings, it is a closed location filled with an ordinary priest who carries a special blessing in his body out to a particular household. Third, when Zechariah comes out of the Temple, he is not able to perform one of the most customary priestly functions: "To pronounce the blessing of the Lord with his lips, and to glory in his name" (Sirach 50:20). The absence of this ability has an important relation to the miracle in his body. But why this absence in the midst of this blessing?

The scene in Luke features remarkable reciprocity between the bodies of Zechariah and Elizabeth. When the messenger by the altar begins to speak, his statements build on the unified relation between the body of Zechariah and the body of Elizabeth asserted in 1:5-7. Zechariah should remove fear from his body, because Elizabeth will have a son in her body. At this point the hearer or reader becomes aware of three preceding events the narration has not recounted: (a) Zechariah has prayed to God; (b) God has heard his prayer; and (c) God has sent the messenger with a special word for Zechariah. This creates a picture of Zechariah speaking with his mouth in a manner that successfully reached the hearing of God. When the messenger speaks, he tells him to remove the fear that has overwhelmed his body (1:12-13). At this point, a sequence of events in the book of Daniel between a messenger from God and Daniel may be instructive. When the messenger comes, he tells Daniel not to fear (mē phobou), because his words have been heard (Dan 10:12, eisēkousthē). Nevertheless, Daniel turns his face toward the ground and becomes speechless (Dan 10:15, esiōpēsa). Daniel is able to open his mouth and speak only after the angel touches his lips (Dan 10:16). It would be possible to think that the fear that overwhelmed 
Zechariah would move him into a state of speechlessness. If it did, the remarkable news that he would soon have a son whom he could name John (1:13-14) removed his speechlessness. When the messenger completes his speech of good news, Zechariah boldly speaks with language that may sound like a challenge of false prophecy. Discussing the problem of false prophecy, Deut 18:20-22 asserts:

${ }^{21}$ You may say in your heart, "How shall I know ( $p \bar{s}$ gnōsometha) the word (to rhèma) that the LORD has not spoken?" ${ }^{22}$ If a prophet speaks in the name of the LORD but the thing does not take place (mé genétai) or prove true, it is a word that the LORD has not spoken. The prophet has spoken it in godlessness; do not withhold your hand from him.

Zechariah speaks to the messenger Gabriel with language that reverberates with reasoning about false prophecy: "How will I know this?" (Luke 1:18, kata ti gnōsomai touto). In the Lukan sequence, Gabriel takes great offense at Zechariah's inquiry. He does not answer Zechariah's question by focusing on God's power to do remarkable things or by reminding Zechariah of Abraham and Sarah, or some other barren couple who had a child late in their lives. He interprets the inquiry as a personal assault on his reliability. Therefore, he presents his identity and credentials as though he had been confronted by an investigating officer: "I am Gabriel. I stand in the presence of God, and I have been sent to speak to you and to bring you this good news" (1:19). The response essentially means: "How could you dare question my identity and status by implying that I could be presenting a false prophecy to you?" The context evidently is very important for the perceived offense. Could a false prophet suddenly appear on the right side of the altar of incense, just outside the Holy of Holies, in the Jerusalem Temple? Gabriel identifies himself through his close relation to God. Gabriel's persona is a full representation of the "presence of God" (1:19, enoppion tou theou) as he stands before Zechariah. Zechariah's speech has implied that false prophecy has come forth from a representative of the presence of God! The punishment of Zechariah is not as severe as death, which came upon Uzzah when he reached out and touched the ark of God (2 Sam 6:6-7). Rather, it is the removal of his ability to function as a priest (Deut 21:5). Without speech he can neither bless God nor pronounce a blessing on the multitude of people gathered in prayer outside the Temple. In contrast to Aaron, the "founding father" of priesthood who had a special task of speaking for his brother Moses, ${ }^{23}$ Zechariah leaves the Temple with no ability to communicate words from God to the people.

The end result of this sequence is an ailment in the body of Zechariah until the day "these things occur" (Luke 1:20, genètai tauta). The special gift of a priest to bless has been removed. Nevertheless, a special gift of life resides in his body as he goes out of the Temple. The multitude waiting outside would have expected Zechariah to pronounce a blessing to God and a blessing on them when he came out of the Temple. In addition, the hearer or reader may have expected that Zechariah would receive a command from the angel to announce a prophetic message to the people, like Isaiah did after his vision of God in the Temple (Isa 6:1-13). In Luke, however, the angel does not touch the lips of Zechariah (cf. Isa 6:7; Dan 10:16) so he can speak. In contrast to Aaron who spoke for Moses, or Isaiah the prophet, Zechariah becomes barren of speech. Zechariah's body now has even a more substantive barrenness in relation to his wife Elizabeth's body as he exits the Temple. Both lack an attribute fundamental to their honor in the realm of their social status.

According to the Lukan story, the people waiting outside interpret Zechariah's inability to speak in precisely the manner one expects from Daniel's speechlessness when God's messenger comes to him: They perceive that Zechariah is not able to speak, because he has

23 Exod 4:14-16, 30; 7:1; 16:9-10. 
seen a vision in the sanctuary $(1: 22)$. But this means that Zechariah is not able either to pronounce a priestly blessing on the people or to prophesy about the birth of John. It is necessary for a miracle to remove this ailment from Zechariah's body. And how will this occur? By means of purposive action by his body that takes him to his home (1:23) and joins him with Elizabeth in the conception of a son (1:24).

The reciprocal relation of the bodies of Zechariah and Elizabeth comes dramatically in view at the end of the scene when Elizabeth speaks. In a context of Zechariah's inability to bless God with his lips, Elizabeth speaks out in prophetic praise in a manner one might have expected Zechariah to speak when he came out of the Temple: "This is what the Lord has done for me when he looked favourably on me and took away the disgrace I have endured among my people" (1:25). This praise of God could just as naturally be on the lips of Zechariah as on the lips of Elizabeth! But Zechariah is unable to speak at this point in the story. An additional miracle must occur before God gives the attribute of speech back to him. This miracle occurs on the eighth day of the life of their son, when he is circumcised and named $(1: 64)$.

\section{Blessing in Sirach 50:22-24 and Zechariah's Blessing in Luke 1:68-79}

At the end of the description of the high priest Simon in Sirach, the final act of the high priest is "to pronounce the blessing (eulogia) of the Lord with his lips, and to glory in his name" (50:20). At this point, the whole congregation of Israelites bows down a second time "to receive the blessing (eulogian) from the Most High" (50:21). Then Ben Sira adds his own benediction:

${ }^{22}$ And now bless (eulogēsate) the God of all,

who everywhere works great wonders (ton megala poiounta),

who fosters our growth (ton hypsounta) from birth,

and deals with us according to his mercy (kata to eleos autou).

${ }^{23}$ May he give us gladness of heart (euphrosunēn kardias), and may there be peace (eirēnē) in our days

in Israel, as in the days of old.

${ }^{24}$ May he entrust to us (empisteusai meth' hèmōn) his mercy (to eleos autou),

and may he redeem (lutrōsasthō) us in our days.

In the context of the circumcision of John at eight days of age, Zechariah "immediately has his mouth opened and his tongue freed, and he begins to speak" (Luke 1:64). Naturally, the speech from Zechariah's lips is priestly when he speaks in the midst of the neighbours who have gathered for the occasion. Zechariah begins by blessing (eulogōn) God (1:64), like the blessing in Sirach 50:22-24 (cf. 45:15), rather than glorifying (doxazōn) God like nonpriestly people do in Luke. ${ }^{24}$ Filled with God's Holy Spirit, when Zechariah prophesies (1:67), his speech is filled with priestly blessing (cf. Exod 7:2). He opens with: "Blessed (eulogetos) be the Lord God of Israel, who has looked with favor and redeemed (epoiesen lutrōsin) his people" (1:68). This has a close relation to the opening and closing of the priestly benediction in Sirach 50:22, 24. As Zechariah continues, he speaks of God doing mercy (to eleos) (1:72), much like Sirach 50:22. In addition, he refers to the people's ability "to serve in holiness and righteousness before him" (1:74-75) all their days, in a manner related to the liturgy of worship in Sirach 50 . When Zechariah speaks directly about the

$24 \quad$ Luke $2: 20 ; 4: 15 ; 5: 25,26 ; 7: 16 ; 13: 13 ; 17: 15 ; 18: 43 ; 23: 47$. 
attributes of John, he speaks again about God's mercy (1:78) and about peace (1:79), like Sirach 50:22-24. When Zechariah states that "the dawn from on high (ex hypsous) will break upon us" by the tender mercy of God (1:78), one is reminded of the high priest in Sirach 50 standing "like the morning star among the clouds" (6) and "the sun shining on the temple of the Most High (hypsistou)" (7). Zechariah has taken Temple worship and blessing as envisioned in Sirach out of the Temple into the hill country where he and Elizabeth live. The body of the child born to Zechariah and Elizabeth creates the context for God's blessings to be present outside the Temple in the midst of God's people.

\section{The House of Mary and the Priestly House of Blessing in Luke 1:26-56}

Zechariah is not the only one responsible for the presence of God's blessings outside the Jerusalem Temple. The angel Gabriel, who "stands in the presence (enoppion) of God" (1:19), was sent by God not only to Zechariah but also to Mary (1:26). The repetition of the "sending" links Gabriel's visit to Zechariah $(1: 19)$ with his visit to Mary $(1: 26){ }^{25}$ When Mary is introduced to the hearer or reader, Lukan discourse adds "kinship" information like it did with Zechariah and Elizabeth. There is no priestly lineage for Mary nor for the house in which she lives. In contrast, the reader or hearer sees in the background "a man named Joseph of the house of David" (1:27), to whom she is "engaged." David, of course, is the "founding father" of "kingship" in Israel. As a result, the episode featuring Gabriel and Mary shifts decisively away from priestly topics to language about kingship. There are, however, important relationships between the discourse in the Mary episode and the scene with the high priest Simon in the Temple in Sirach 50. When Gabriel speaks to Zechariah, he refers to "the Lord" $(1: 15,17)$, "God" (1:19), and the "Lord God" $(1: 16)$. When Gabriel speaks to Mary, he not only refers to "the Lord" (1:28), "God" $(1: 30,35,37)$, and "Lord God" (1:32) but also to the "Most High" $(1: 32,35)$. In the midst of language about "the Lord" (Sirach 50:17, 19, 20) ${ }^{26}$ Sirach shifts decisively to "Most High" as the title for God (Sirach $50: 7,14,15,16,17,19,21$ ). This language about God is further intensified by reference to God as "the Almighty" (pantokratōr) in Sirach 50:14, 17. In Sirach, the Jerusalem Temple is not only a place for God's "holy" power but a place for God's "mighty" power. This emphasis is present in the high priest Simon's "fortifying" of the Temple (50:1, 4) and in the emphasis on "peace" in the benediction (50:23). In Luke 1:2638 , Gabriel moves this language outside the Jerusalem Temple into the house of Mary. ${ }^{27}$

When Gabriel brings God's mighty power into the Davidic house of Mary, he concludes his speech with reference to the pregnancy of her kinswoman Elizabeth (1:36). As a result, as soon as the angel departs from her, Mary "makes haste to a Judean town in the hill country" (1:39) to visit her. When Mary "enters the house of Zechariah" (1:40), much like Zechariah "entered the sanctuary of the Lord" (1:9), Elizabeth is filled with Holy Spirit in the presence of Mary's pregnant body (1:41), much like Zechariah later is filled with Holy Spirit in the presence of his eight day old son $(1: 67) .{ }^{28}$ Gabriel told Zechariah that John

25 Lukan discourse says that the angel Gabriel was sent "from God to (eis) a city ... to (pros) a virgin .... and the virgin's name was Mary" (1:26-27).

26 In Ben Sira's benediction, there is a reference to "the God of all" (Sirach 50:22).

27 Along with an emphasis on God "Most High" in Sirach 50, there is an emphasis on God's "mercy." Both Ben Sira's benediction and Zechariah's priestly prophecy refer to God's mercy (Sirach 50:22, 24; Luke 1:72, 78). In a context of reference to God "Most High," Sirach 50:19 refers to the people's prayers "before the Merciful One" (katenanti eleēmonos).

28 The anarthrous references to Holy Spirit refer to God's spirit and power in a manner that is not Trinitarian, though they helped to prepare the way for Trinitarian doctrine: Fitzmyer (1981, 350-351). 
would be filled with Holy Spirit before his birth (1:15). The coming of the Holy Spirit upon Mary in her own household (1:35) makes her a bearer of Holy Spirit outside her household to Elizabeth, much like Zechariah brought God's miraculous powers of birth from the Jerusalem Temple to Elizabeth. Elizabeth's house becomes a "house of blessing" when Mary enters it. Elizabeth's body, "filled with Holy Spirit" (1:41), functions in a manner that makes her home an inner sanctum of blessing both for Mary and for Jesus. When Elizabeth speaks to Mary, she speaks in the manner of a priest. Elizabeth begins by blessing Mary among women (1:43a). Adopting a priestly role, Elizabeth's blessing evokes the presence of "all women" as she "ritualizes" Mary's status as a person "favored by God" $(1: 28,30)$. The house of Zechariah and Elizabeth has become a special "house of God" that not only includes two women but also invokes the presence of all women through its priestly activity! After the blessing on Mary, Elizabeth blesses the fruit of Mary's womb (1:42b). Elizabeth's house becomes the location for the priestly wife Elizabeth to be the first human to bless the son who will be named Jesus (1:31). But her speech also participates in another dynamic in the discourse. Gabriel assured Mary that her son would be "holy" (1:35, hagion) as a result of the role of God's Holy Spirit in her pregnancy. Through Elizabeth's speech, the activity of God's Holy Spirit returns to Mary in the form of a holy, priestly blessing on Mary's son Jesus. Elizabeth has become a mediator of the blessings of God's Holy Spirit back to Mary. Elizabeth concludes her priestly activity with the pronouncement of beatitude. This shifts the second person address of all of her previous speech to a third person announcement of the blessedness of Mary: "Blessed is she who believed that there would be a fulfillment of what was spoken to her by the Lord" (1:45). To whom is this beatitude addressed? It is as though all the hearers or readers have become a congregation of people participating in worship at Elizabeth's house. The beatitude Elizabeth speaks is a response to the "joy" (1:44, agaliasis) of the child in her body. The mode of Elizabeth's speech is related to the shouting, the trumpeting, and the singing in the midst of the blessings in the Jerusalem Temple in Sirach 50:16-21. In this final act, Elizabeth functions not only as priest but also as a son of Aaron, a trumpeter, and a singer! The blessedness of Mary, which causes the child in Elizabeth's womb to leap for joy, brings forth beatitude from Elizabeth that tells the story of a woman who believed what was spoken to her by the Lord. After Elizabeth's beatitude, Mary fulfills the role of the joyous congregation by responding with a song of joy and gratitude for all of God's mighty and merciful works $(1: 46-55)$.

As noted above, the priest Zechariah is absent from the scene with Mary and Elizabeth. During this time, we must remember, Zechariah is not able to speak. As a mute priest, he has no place in the scene. Only women blessed with child are present in this priestly house and its activity of worship. The presence of these pregnant women creates the context for God's Holy Spirit to be active both in the women and in the children in their bodies. But more than this happens as Elizabeth functions as the priest who gives blessings in "Zechariah's house" (1:40). If Sirach has "told" a Jerusalem Temple where Woman Wisdom has been taken into, or excluded from, a "male inner sanctum" which functions as a "womb of holiness" (cf. Camp 2002, 78-80; Jay 1992, 40), the house of Zechariah and Elizabeth puts significant pressure on this tradition. Fecundity of holiness is present in the house of Elizabeth, and priestly blessing flows from the mouth of a priestly wife onto a pregnant woman who brought God's Holy Spirit into her house. When the child in Elizabeth's womb leaps for joy, she participates in the joy of her child by pronouncing beatitude of blessing. Zechariah's priestly wife functions as a priest in the absence of the male priest who usually could pronounce the blessings. In "their own house of holiness" in a Judean town in the hill country, the balance has tipped from priestly activity by a man to 
priestly activity by a woman. Women are centrally present in this "holy place." As the powers of God have moved outside the Jerusalem Temple, women have become the priestly mediators of God's blessings to two very important men in the story of God's renewal of Israel.

\section{Blessing the Infant Jesus and his Return to the Temple in Luke 2:21-52}

After a simple reference to the circumcision of Jesus on the eighth day and the naming of him according to the name given by the angel (2:21), the Gospel of Luke presents a scene of "cleansing" in the Jerusalem Temple according to the law of Moses (2:22) ${ }^{29}$ At this point, the Torah discourse that began in 1:6 with the description of Zechariah and Elizabeth continues in narration about Jesus. The beginning (2:22-24), middle (2:27), and end (2:39) of the narration contains five references to "the law." This establishes a context of righteous performance of Torah throughout the scene that rivals the introduction of Zechariah and Elizabeth to the hearer or reader at the beginning of the story. The repetitive texture of the narration is remarkable as it refers to "according to the law of Moses" (2:22), "as it is written in the law of the Lord" (2:23), "according to what is stated in the law of the Lord" (2:24), "according to what was customary under the law" (2:27), and "everything according to the law of the Lord" (2:39). The overall scene creates a sequence of faithful ritual performance in the Temple, followed by prophetic speech and blessing, that is related to the scene with Zechariah in the Temple and the scene with Elizabeth and Mary after it. The body of the infant Jesus, which the angel assured Mary would be born "holy" (1:35), is taken into the Jerusalem Temple and "presented to the Lord" through a ritual sacrifice of "a pair of turtle doves or two young pigeons" (2:22-24). The effect of this ritual is to enact the name of Jesus as "holy" not only in Mary's "house of David" but also in the Jerusalem Temple. Fifty Greek words describe the detail of this activity with an even greater specificity of detail than the narration that described Zechariah's offering of the incense in 1:8-10. Much as the incense offering created a picture of bodily devotion in the Temple that brings forth God's miraculous powers in the form of a child "filled with the Holy Spirit" $(1: 15,41)$, so the "cleansing" creates a picture of bodily devotion in the Temple that secures the "holiness" of the firstborn child (2:23) which the Holy Spirit brought into being in the body of Mary (1:35). Performance of Torah in the Jerusalem Temple is a means by which "priestly" holiness transfers from the context of the Temple to the bodies of both John the Baptist and Jesus.

Instead of the sudden appearance of a messenger of the Lord in the context of the cleansing offering, a righteous and devout man named Simeon and a fasting and praying prophet named Anna come forward and performed actions of blessing and prophecy. These two "temple-bodies" create a picture of a space of blessing in the Jerusalem Temple that is open to both men and women. In other words, instead of the cleansing offering being on the inside in the sanctuary $(1: 9,21-22$, naos $)$ while the parents and the child are praying outside (cf. 1:8-23), the Jerusalem Temple is a space of blessing (2:26, 37, hieron) open to both women and men. ${ }^{30}$ The infant Jesus and his parents $(2: 27,33)$ enter the Temple, and a special man and woman come forward and bless not only the child but also the parents (2:34). The narration endows Simeon with holy spirit three times $(2: 25,26,27)$ as it describes his "righteous and devout expectation" (2:25), the promise that he "would not see death before he had seen the Lord's Messiah" (2:26), and his entrance into the Temple

29 Either "their" cleansing or "his" (Jesus') cleansing.

30 Hieron obviously refers to an open court of the Jerusalem Temple, rather than the "closed" sanctuary (naos): Fitzmyer $(1981,427)$. 
(2:27). Then it pictures him taking the child into his arms, "blessing God," and speaking (2:28). Simeon is clearly an embodiment of the Holy Spirit in the location of the Jerusalem Temple! When Simeon speaks, his references to peace (2:29), salvation "before the face of all people" (2:30-31), and "glory to your people Israel" (2:32) creates the picture of the Jerusalem Temple as a special place of "revelation to nations."

When Simeon finishes speaking, he blesses (eulogēsen) Jesus' father and mother, again in the manner of a priest. ${ }^{31}$ When he speaks to Jesus' mother Mary about the destiny of her child, he refers to the falling (ptōsis) of many in Israel with language that relates in a special way to the description of the activities of the high priest Simon in Sirach 50. At the end of the description of all the good things Simon did for the Temple and the city of Jerusalem, the narration states that "he considered how to save his people from ruin (ptōsis), and fortified the city against siege" (50:4). While the image of rising and falling has a close relation to Isa $8: 14-15,{ }^{32}$ the Greek word ptōsis has a special place in the LXX of Isa 51:17:

Rouse yourself, rouse yourself! Stand up (anastēthi), O Jerusalem,

you who have drunk at the hand of the Lord the cup of his wrath,

For the cup of ruin (ptōsis), the bowl of wrath, you have drunk and you have emptied. ${ }^{33}$

The "ruin" to which Isaiah refers is the same kind of "falling" which concerned the high priest Simon in Sirach 50:4. This "falling" is also on the lips of Simeon as he stands before Jesus and his parents, and it appears to have a special relation to the destruction of Jerusalem to which Jesus refers in Luke 21:24: "And Jerusalem will be trampled on by the nations, until the times of the nations are fulfilled."

"Finishing everything" according to the Torah of the Lord while Jesus is an infant (Luke 2:39) results in the child Jesus growing, becoming strong, and becoming "filled with wisdom" (2:40). In this way the "favour" (charin) of God was upon him. In other words, the blessing in the priestly house of Zechariah and Elizabeth, and the "cleansing" of Jesus in the Jerusalem Temple, result in "wisdom" in Jesus. This is a reversal of the movement of God's powers in Sirach, where God's wisdom moves into the holiness of the Temple.

When Jesus is twelve years old, he returns dramatically to the Temple. He does not return in a priestly mode, but in the mode of a person filled with wisdom. When Jesus enters the Temple, the hearer or reader begins to view the Temple as a place of teaching! Instead of being primarily a closed sanctuary or primarily a court of blessing, it begins to become a place where people gather to receive special wisdom from God. As the narrative progresses, Jesus will return to the Temple as a prophetic teacher who reconfigures the Temple into a household where his followers can gather to receive the Holy Spirit for their work in the world 22:44-53). The stage is set for this in Luke 2:41-52.

When Jesus' parents find Jesus in the Temple after the festival of Passover, he is "sitting among the teachers (didaskalōn), listening to them and asking them questions" (2:46). All who heard him were "amazed at his understanding (sunesi) and his answers" (apokrisesin) (2:47). The twelve year old Jesus does not go to the Temple to pray, to give or receive a blessing, to offer forgiveness, or to give praise to God. This young man, who received blessing from the priestly house of Zechariah and Elizabeth, and from the

1 Sam 2:20; Num 6:23-27; Gen 14:18-19.

Cf. Luke 20:17-18; 1:51-53.

3 Another passage is LXX Jer 6:13-15: For from the least of them to the greatest, everyone carries out lawlessness, from priest even unto false prophet all act falsely. They have healed the affliction of my people with spitefulness, and they say, "Peace, peace," where there is no peace ... therefore they will fall in their ruin (ptōseōs); at the time of their visitation (episkopēs) they will be destroyed, says the Lord. 
Jerusalem Temple, already embodies these blessings in the form of a person filled with remarkable wisdom. After Jesus establishes contact with John the Baptist (Luke 3:21-23) and spends time in the wilderness (4:1-13), his wisdom becomes prophetic wisdom (4:1819) rather than priestly wisdom. This Christian story recounts the transmission of God's powers from the Jerusalem Temple through priestly procedures into a prophetic teaching Messiah who preaches good news to the poor, heals the blind, lame, and maimed, and raises people from the dead! As the story comes to an end in the Gospel of Luke, the Jerusalem Temple has become a space where men and women can gather much as they did in Sirach 50. Instead of receiving blessings from the rituals of a glorious high priest, however, these people receive God's Holy Spirit while hearing the preaching of prophetic wisdom (Acts 2). The Jerusalem Temple remains a place of God's power, but a new story of "important persons" begins to "tell" the Temple in ways that present decisively new challenges for the story of Israel.

\section{Conclusion}

The Gospel of Luke features an amazing amount of "blessing" in its opening chapters. Elizabeth blesses Mary "among women," and she blesses the child in Mary's womb (1:42). Zechariah blesses God when his mouth is opened and his tongue is freed (1:64), and he blesses God again when he begins to speak about the child John (1:68). Simeon blesses God when he sees Jesus in the Temple as an infant (2:28). Then Simeon blesses Jesus' parents and communicates a special message to Mary (2:34). In addition, the Gospel of Luke contains an amazing focus on priestly people and priestly rituals. The story begins with a priestly offering of incense by Zechariah, and it emphasizes that both Zechariah and Elizabeth are members of priestly families. Then a priestly offering is made by Jesus' parents, and the narration emphasizes that these activities fulfilled the Torah of the Lord in the Temple.

The priestly activity at the beginning of the story bears fruit in a "prophet in the wilderness" named John, whom tax collectors called "Teacher" (3:12), and in a "prophet who preaches good news to the poor" named Jesus (4:18). God's powers have moved out of the Jerusalem Temple into the bodies of two people who reform society, households, and the Temple through their prophetic teaching. Jesus returns to the Jerusalem Temple as an adult to reform it with his teaching (Luke 20:1-38). The priestly powers that went out of the Temple now come back into the Temple as prophetic wisdom in the body of Jesus. This prophetic wisdom reconfigures the Temple into a "household" where Jesus' followers themselves perform the priestly activity of blessing God daily (24:33, eulogountes). In Luke, then, the "telling" of the Temple at the beginning of the story has a dynamic relation to the "telling" of the Temple at the end of the story. At the beginning, God's miraculous powers move through an angel and a priest out from the Jerusalem Temple into households. At the end, people move from their households into the Jerusalem Temple, where they become the new "bodies" who will take God's power out into cities, towns, and households throughout the Mediterranean world. 